\title{
Evaluation of Quality Protein Maize (QPM) Genotypes under Rainfed Mid Hill Environments of Nepal
}

\author{
S.R. Upadhyay ${ }^{1}$, D. B. Gurung ${ }^{1}$, D.C. Paudel ${ }^{1}$, K. B. Koirala ${ }^{2}$, S. N. Sah ${ }^{3}$, \\ R. C. Prasad ${ }^{4}$, B. B. Pokhrel ${ }^{1}$ and R. Dhakal ${ }^{5}$. \\ ${ }^{\prime}$ National Maize Research Programme (NMRP), Rampur, Chitwan \\ ${ }^{2}$ Regional Agriculture Research Station Lumle, Kaski \\ ${ }^{3}$ Agriculture Research Station, Pakhribas \\ ${ }^{4}$ Hill Crops Research Programme, Kabre, Dolakha, ${ }^{5}$ Agriculture Research Station, Dailekh \\ e-mail : sheshupot@yahoo.com
}

\begin{abstract}
Maize (Zea mays L.) is the second most important staple food crop after rice and a major food crop of the resource poor people in the hills of Nepal. Prevailing normal maize (non-QPM) is deficient in two essential amino acids, lysine and tryptophan. The majority of hill farm families are suffering from protein malnutrition as their major diet is maize and cannot afford animal protein. QPM contains opaque-2, a single gene mutation that alters the protein composition of the endosperm portion and nearly double the essential amino acids concentrations than the normal maize grain. The biological value of protein in QPM maize is about $80 \%$, that of milk is about $90 \%$ and in normal maize (non-QPM) is about $45 \%$ only. A series of experiments were conducted in RCB Design during 2004/2005 summer season and superior genotypes selected and promoted from Observation Nurseries to IYT and CVT (Coordinated Varietal Trial) respectively. CVTs were evaluated across mid-hills of Nepal. Based on four environmental mean results in CVT: the genotype S99TLWQ- HG-AB (QPM maize) produced the highest mean grain yield ( $4899 \mathrm{~kg} \mathrm{ha}^{-1)}$ followed by Population $44 \mathrm{C}_{10}\left(4552 \mathrm{~kg} \mathrm{ha}^{-1}\right)$ and Manakamana-3 (4436 kg ha-1) respectively. However, most of the tested QPM genotypes were at par with improved check for grain yield production and significantly highest grain yielder than the farmres' variety (local check). Concluding results revealed that the genotype S99 TLWQ-HG-AB performed very well across the mid hills. Findings of the present study will help to reduce protein malnutrition problem in the hills of Nepal.
\end{abstract}

Key words: GGE-biplot, genotype x environment interaction, normal maize, open pollinated varieties (OPV), Quality protein maize (QPM).

\section{Introduction}

Maize (Zea mays L.) is the second most important cereal crop after rice in Nepal, and a major food crop in the hills. The total area under maize is $8,70,401$ ha in Nepal. Out of this area, $70.07 \%(5,96,293 \mathrm{ha})$ belongs to mid hills and $10.42 \%(88,697 \mathrm{ha})$ to high hills, with the productivity of $2091 \mathrm{~kg}^{\text {-ha }}$ and $1728 \mathrm{~kg}^{-}$ ha respectively (ABPSD, 2006-2007). The majority of hill farm families especially infants, pregnant and lactating women, and elderly persons are suffering from quality protein malnutrition. Considering this problem the present study was undertaken for the identification, development, and promotion of QPM varieties for general cultivation in the hills (Upadhyay et al. 2002 and 2004). All the OPVs and hybrid varieties of maize released so far are normal type. Their nutritional quality is poor as they are deficient of two essential amino acids, lysine and tryptophane. New QPM synthetics have special characteristic features such as low and uniform ear placement, resistance to ear rot and root lodging and most notably levels of tryptophan $(0.11 \%$ of the whole grain), lysine $(0.475 \%$ of the whole grain $)$ and protein $(11.0 \%$ of the whole grain) far beyond those contained in normal maize $(0.05 \%, 0.225 \%$ and $8.5 \%)$. These features make the QPM synthetics / OPVs particularly attractive to farmers (Hugo 2000). 
The nutritional benefits of QPM for people, who depend on maize for their energy and protein intake and for other nutrients, are indeed quite significant. Metrz et al. first reported that the lysine content in Opaque 2 (O2) was 3.3 to $4.0 \mathrm{~g}$ per $100 \mathrm{~g}$ of endosperm protein, which was more than twice that of normal maize endosperm ( $1.3 \mathrm{~g}$ lysine per $100 \mathrm{~g}$ endosperm protein). Several researchers later demonstrated the superior protein quality and its digestibility of QPM over normal maize (Paes M et al 1995, Bressani 1995, Graham et al. 1980). The studies indicated that the QPM protein contains, in general, 55\% more tryptophan, 30\% more lysine and 38\% less leucine than that of normal maize (Paes M et al 1995). Lysine and tryptophan are the most essential amino acids for protein synthesis in human and monogastric animals. For humans, lysine is the most limiting amino acid followed by tryptophan in maize protein (Kies et al. 1965).

At least four studies on children and four on adults have found that eating QPM had significantly higher nitrogen retention than those who ate normal maize (Bressani 1991), indicating QPM protein is more "bioavailable" (NRC 1988). The biological value of QPM protein is about $80 \%$ that of milk which is about $90 \%$ and that of normal maize is only about $45 \%$ (FAO 1992).

QPM also provides better quality feed and fodder to poultry, cattle, swine, and fishmeal industries.

\section{Materials and Methods}

\section{Field tests}

A series of Observation Nurseries (obtained from CIMMYT) were evaluated since 1998. Superior genotypes were selected and promoted from these Nurseries to IYT and CVT respectively. On station, experiments (CVT) were conducted across the mid-hills namely Dailekh, Lumle, Kabre and Dhankuta in RCB design during 2004/2005 summer seasons (March to September). Each experimental plot of $9.0 \mathrm{~m}^{2}$ was seeded at the standard seed rate of $20 \mathrm{~kg} \mathrm{ha}^{-1}$ and net area harvested was $4.5 \mathrm{~m}^{2}$. The spaces between row-to-row and plant to plant were 75 and $25 \mathrm{~cm}$. respectively. Two seeds per hill were planted and thinned to a single plant per hill after first weeding. Fertilizers were applied at the rate of 120:60:40 kg ha-1 $\mathrm{N}: \mathrm{P}_{2} \mathrm{O}_{5}: \mathrm{K}_{2} \mathrm{O}$ respectively in addition to $15 \mathrm{t}$ farmyard manure ha- ${ }^{-1}$. Half dose of $\mathrm{N}$ and full doses of $\mathrm{P}$ and $\mathrm{K}$ were applied basally. The remaining half of $\mathrm{N}$ was applied as side dressing at knee-high stage. The plots were kept free of weeds manually. Traits in each plot were recorded: days to $50 \%$ tasseling and silking (5 plants in each plot), plant and ear height 2-3 weeks after flowering and all the plants and ears in each plot were counted. Data on plant aspects (plant and ear height, uniformity of plants, disease and insect damage and lodging) in each plot were recorded at the brown husk stage on a scale of 1 to 5 , where 1 and 5 represent excellent and poor respectively. At maturity, husk cover was rated on a scale of 1 to 5 , where 1 represents husk tightly covering the ear tip and extending beyond it and 5 signifies clearly exposed tips. After harvest, all ears from a plot were placed in a pile and ear aspects (size, disease and insect damage, grain filling and uniformity) were recorded on a scale of 1 to 5 , where 1 and 5 signify the best and poorest respectively. The plots were harvested individually. Grain yield was adjusted to $80 \%$ shelling recovery from the de-husked cob weight/plot. Grain moisture content for each plot was recorded and grain yield was adjusted to $15 \%$ percent moisture basis.

MSTATC, Excel and the GGE-biplot analysis system were used for statistical analyses.

\section{Varietal stability test}

To determine stability and identify superior genotypes across environments, genotype and genotype $\mathrm{x}$ environment (GGE) bi-plot analysis was conducted using GGE bi-plot software (Yan \& Kang 2002). This method defines the position of an ideal genotype, which will have the highest average value of all genotypes and be absolutely stable; that is it expresses no genotype by environment interaction. The ideal genotype is used as a reference to rank the other genotypes. A performance line passing through the origin of bi-plot is used to determine the mean performance of a genotype. The arrow on the performance line represents increasing mean performance. A stability line perpendicular to the performance line also passes through the origin of the bi-plot; the two arrows in opposite directions represent decrease in stability. A genotype closer to the performance line is considered more stable than the one placed farther (Fig. 1).

Regression analysis was also performed to determine stability and identify superior genotypes across environments on the basis of regression coefficient (Fig. 2). 
S.R. Upadhyay et al./Evaluation of Quality

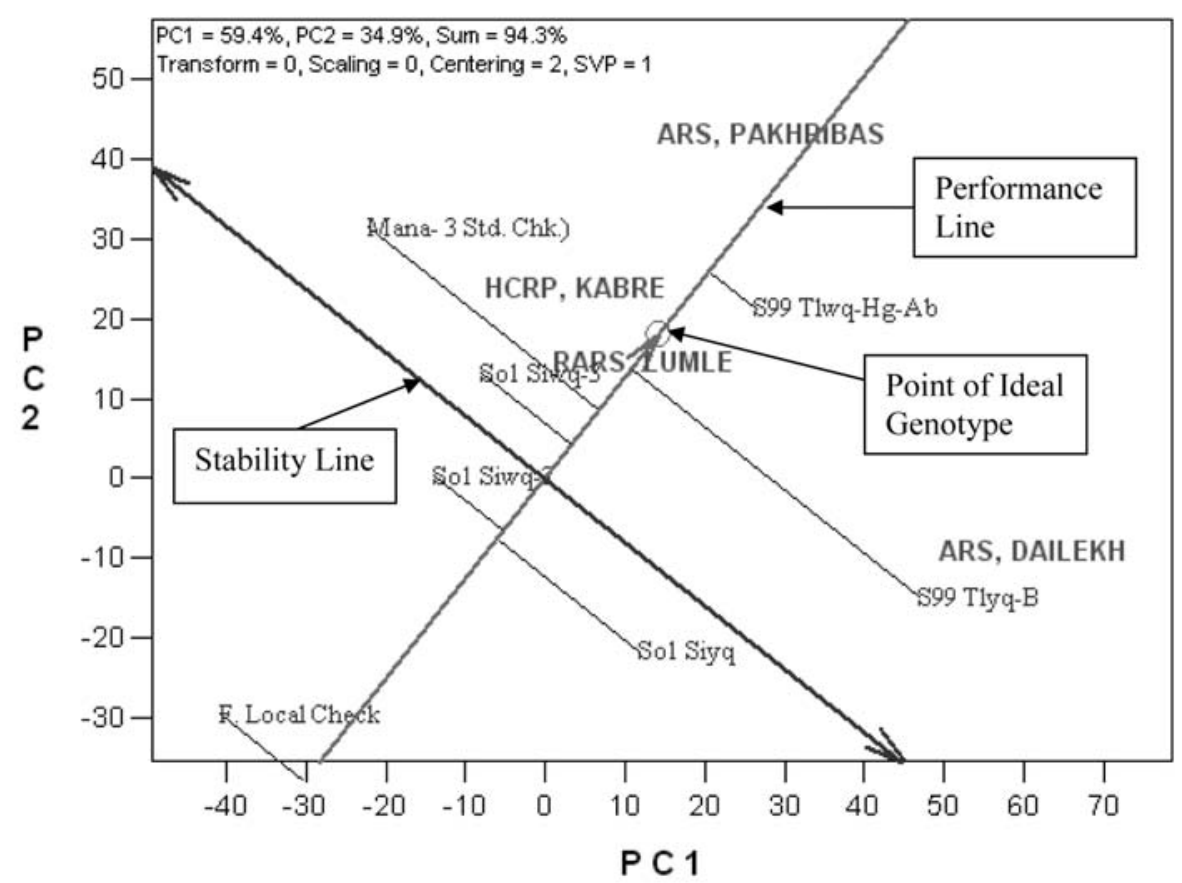

The Average Tester Coordination view

Fig. 1 GGE bi-plot showing comparison of 7 maize genotypes with an ideal genotype for grain yield tested on farm across 4 hill environments of Nepal
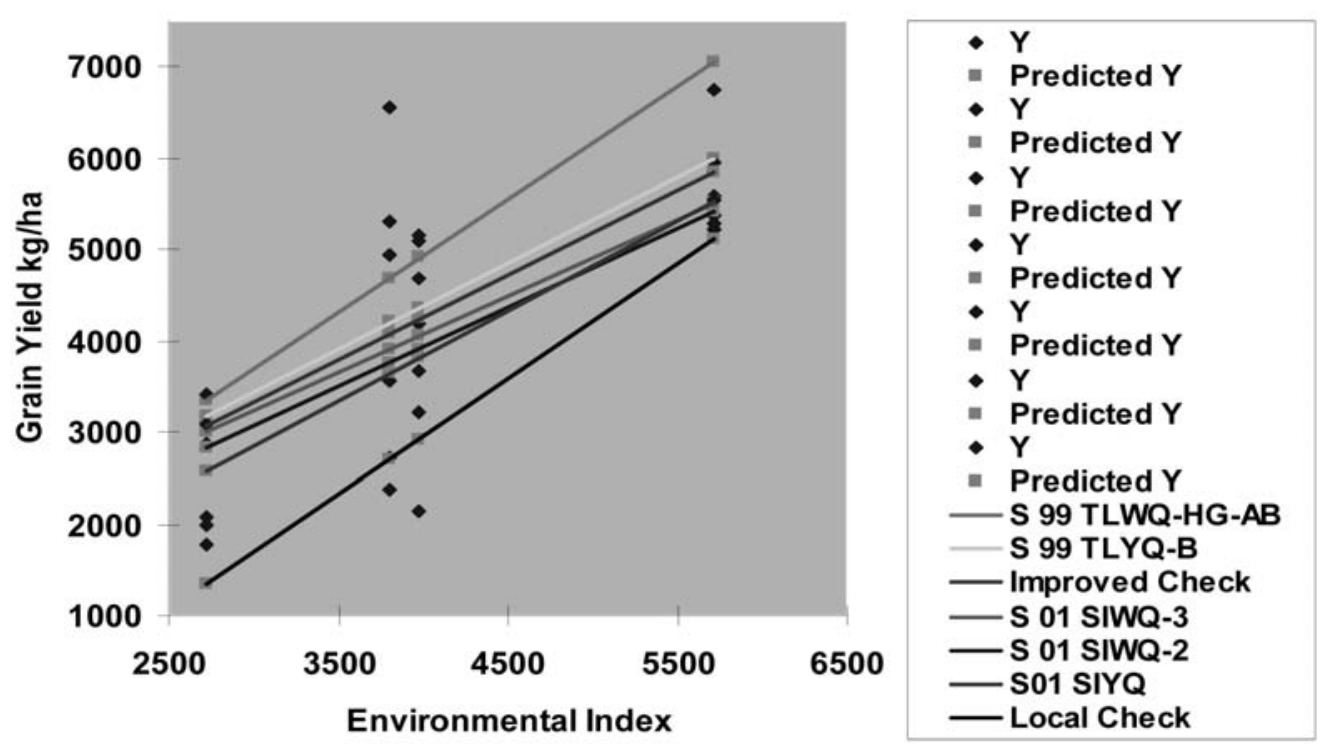

Fig. 2 Pattern of stability for grain yield of QPM maize genotypes in CVT across 4 hill environments of Nepal 


\section{Results and Discussion}

Results of 2005 summer season revealed that out of 11 genotypes evaluated including 7 QPM OPVs and 4 normal maize, the genotype S99 TLWQ-HG-AB produced the highest grain yield ( $4899 \mathrm{~kg} \mathrm{ha}^{-1}$ ) followed by Population $45 \mathrm{C} 10$ (4552 $\left.\mathrm{kg} \mathrm{ha}^{-1}\right)$ and Manakamana-3 (4436 kg ha-1) improved check (normal maize) respectively across hill environments. These QPM genotypes were statistically at par with improved Check and significantly superior $(\mathrm{P}=>0.01)$ than the Farmers' Local Check variety. However all the tested QPM genotypes were significantly higher grain yielders than the Farmers' Local Variety. For days to $50 \%$ flowering
Farmers' Variety was earliest followed by Corralejo -S99 SIWQ and Celaya S91 SIWQ respectively. Genotype S99 TLYQ-B was statistically earlier and S99 TLWQHG-AB was at par for days to $50 \%$ flowering than the improved check. Genotype Corralejo -S99 SIWQ had the significantly shortest ear height $(77 \mathrm{~cm})$ followed by Population $45 \mathrm{C} 10(91 \mathrm{~cm})$ and S01 SIWQ-3 $(92 \mathrm{~cm})$ respectively. Farmers' Local had the tallest ear height $(118 \mathrm{~cm})$ followed by S99TLYQ-B $(100 \mathrm{~cm})$ and Population $44 \mathrm{C} 10$, S99 TLWQ-HG-AB $(96 \mathrm{~cm})$ respectively. All the tested genotypes were significantly different for plant height (Table 1). For environment wise grain yield performance, please refer Table 2.

Table 1. Combined results of CVT, QPM hill set (Lumle, Pakhribas, Dailekh and Kabre) Summer 2005

\begin{tabular}{|c|c|c|c|c|c|c|c|c|c|c|}
\hline $\begin{array}{r}\text { Trt. } \\
\text { No. }\end{array}$ & Genotypes & $\begin{array}{c}\text { Days to } \\
50 \% \\
\text { Flowering } \\
\text { Female }\end{array}$ & $\begin{array}{l}\text { Pl. ht. } \\
\mathrm{cm} .\end{array}$ & $\begin{array}{l}\text { Ear } \\
\text { ht. } \\
\mathrm{cm} .\end{array}$ & $\begin{array}{l}\text { Husk } \\
\text { Cov } \\
(1-5)\end{array}$ & $\begin{array}{l}\text { P1 } \\
\text { Asp } \\
(1-5)\end{array}$ & $\begin{array}{c}\text { Ear Asp } \\
(1-5)\end{array}$ & $\begin{array}{l}\text { E. tur. } \\
(1-5)\end{array}$ & $\begin{array}{c}\text { Adjusted } \\
\text { grain } \\
\text { yield } \mathrm{kg}^{\text {-ha }}\end{array}$ & $\begin{array}{c}\text { DMRT } \\
\text { Test }\end{array}$ \\
\hline 1 & S99 TLYQ-B & 81 & 202 & 100 & 1.8 & 2.3 & 2.0 & 2.9 & 3934 & $\mathrm{ABCD}$ \\
\hline 2 & S99 TLWQ-HG-AB & 83 & 198 & 96 & 2.4 & 1.8 & 2.0 & 2.8 & 4899 & $\mathbf{A}$ \\
\hline 3 & Celaya S91 SIWQ & 78 & 183 & 87 & 2.3 & 2.7 & 2.2 & 2.4 & 3821 & $\mathrm{BCD}$ \\
\hline 4 & Corralejo S99 SIWQ & 76 & 177 & 77 & 2.5 & 2.8 & 3.3 & 2.6 & 3440 & $\mathrm{CD}$ \\
\hline 5 & SO1 SIWQ-2 & 80 & 193 & 84 & 2.0 & 2.5 & 2.3 & 2.9 & 4300 & $\mathrm{ABC}$ \\
\hline 6 & SO1 SIWQ-3 & 83 & 196 & 92 & 1.9 & 2.2 & 2.2 & 3.2 & 4204 & $\mathrm{ABCD}$ \\
\hline 7 & SO1 SIYQ & 80 & 191 & 88 & 2.5 & 2.3 & 2.5 & 2.3 & 3633 & $\mathrm{BCD}$ \\
\hline 8 & Population $45 \mathrm{c} 10$ & 80 & 200 & 91 & 2.5 & 2.4 & 2.5 & 2.5 & 4133 & $\mathrm{ABCD}$ \\
\hline 9 & Population $44 \mathrm{c} 10$ & 80 & 207 & 96 & 2.2 & 2.3 & 2.4 & 2.5 & 4552 & $\mathrm{AB}$ \\
\hline 10 & Manakamana 3 & 85 & 215 & 108 & 1.7 & 2.1 & 1.6 & 2.0 & 4436 & $\mathrm{ABC}$ \\
\hline \multirow[t]{7}{*}{11} & F. Local & 73 & 220 & 118 & 2.0 & 2.9 & 2.4 & 2.5 & 3191 & $\mathrm{D}$ \\
\hline & Grand Mean & 80 & 198 & 94 & 2.2 & 2.4 & 2.3 & 2.6 & 4049 & \\
\hline & Genotype (G) & $* *$ & $* *$ & $* *$ & NS & NS & $*$ & & $*$ & \\
\hline & Environment (E) & $* *$ & $* *$ & $* *$ & $* *$ & $* *$ & $* *$ & & $* *$ & \\
\hline & $G \times E$ & $* *$ & $*$ & $* *$ & - & - & NS & NS & & \\
\hline & $\mathrm{C} \mathrm{V} \%$ & 3.3 & 9.67 & 13 & 45.42 & 45.1 & 38.8 & 44.1 & 27.75 & \\
\hline & LSD $(0.05)$ & & & & & & & 1.42 & 913 & \\
\hline
\end{tabular}

Covariance analysis of grain yield ( $\mathrm{kg}^{\text {-ha }}$ ) by number of plants (per ha) as covariate was performed to calculate the adjusted grain yield.

\begin{abstract}
Abbreviations
Pl. ht. $\mathrm{cm} .=$ Plant height in centimeters; Ear ht. $\mathrm{cm}$.

$=$ Ear height in centimeters; Pl. Asp. (1-5) = Plant aspects $1=$ best to $5=$ worst/ very poor; Ear Asp. $=$ Ear aspects $1=$ best to $5=$ worst) and E. turcicum
\end{abstract}

$(1-5)=$ Exserohilum turcicum causes Northern Leaf Blight (NLB)/ Turcicum Leaf Blight (TLB) an important disease of maize in Nepal $1=$ Highly Resistant to 5= Highly Susceptible. 
Table 2. Combined analysis of CVT - QPM maize for grain yield (kg/ha) at LAC, PAC, Dailekh and HCRP Kabre, Summer 2005 .

\begin{tabular}{|c|c|c|c|c|c|c|c|c|c|}
\hline $\begin{array}{l}\text { Tre } \\
\text { atment }\end{array}$ & Genotypes & $\begin{array}{l}\text { RARS, } \\
\text { Lumle }\end{array}$ & $\begin{array}{l}\text { ARS, } \\
\text { Pakhribas }\end{array}$ & $\begin{array}{c}\text { DMR } \\
\text { Test }\end{array}$ & $\begin{array}{c}\text { ARS, } \\
\text { Dailekh }\end{array}$ & $\begin{array}{c}\text { HCRP, } \\
\text { Kabre } \\
(1740 \mathrm{~m} \text { asl })\end{array}$ & $\begin{array}{c}\text { DMR } \\
\text { Test }\end{array}$ & $\begin{array}{l}\text { Mean of } \\
4 \text { Locat.s }\end{array}$ & $\begin{array}{l}\text { DMR } \\
\text { Test }\end{array}$ \\
\hline 1 & S99 TLYQ-B & 5229 & 4183 & $\mathrm{AC}$ & 6559 & 1773 & $\mathrm{D}$ & 3934 & $\mathrm{ABCD}$ \\
\hline 2 & S99 TLWQ-HG-AB & 6754 & 5097 & $\mathbf{A}$ & 5300 & 2847 & $\mathrm{ABCD}$ & 4899 & A \\
\hline 3 & Celaya S91 SIWQ & 5264 & 3577 & $\mathrm{ABCD}$ & 4986 & 3430 & A & 3821 & $\mathrm{BCD}$ \\
\hline 4 & Corralejo S99 SIWQ & 4815 & 2930 & $\mathrm{CD}$ & 2373 & 2671 & $\mathrm{ABCD}$ & 3440 & $\mathrm{CD}$ \\
\hline 5 & SO1 SIWQ-2 & 5577 & 3673 & $\mathrm{AB}$ & 3561 & 3091 & $\mathrm{AB}$ & 4300 & $\mathrm{ABC}$ \\
\hline 6 & SO1 SIWQ-3 & 5367 & 4678 & $\mathrm{BCD}$ & 3566 & 2864 & $\mathrm{ABC}$ & 4204 & $\mathrm{ABCD}$ \\
\hline 7 & SO1SIYQ & 5291 & 3224 & $\mathrm{AB}$ & 4949 & 2083 & $\mathrm{BCD}$ & 3633 & $\mathrm{BCD}$ \\
\hline 8 & POpulation 45 c10 & 6339 & 4094 & BCD & 3128 & 2604 & $\mathrm{ABCD}$ & 4133 & $\mathrm{ABCD}$ \\
\hline 9 & Population 44 c10 & 6683 & 4975 & $\mathrm{ABC}$ & 2225 & 3100 & $\mathbf{A B}$ & 4552 & AB \\
\hline 10 & Manakamana 3 & 5951 & 5161 & A & 2728 & 3408 & A & 4436 & $\mathrm{ABC}$ \\
\hline \multirow[t]{8}{*}{11} & F. Local & 5551 & 2148 & A & 2371 & 1995 & CD & 3191 & D \\
\hline & Grand Mean & 5711 & 3976 & & 3795 & 2715 & & 4049 & \\
\hline & F- Test & NS & $* *$ & & NS & * & & & \\
\hline & CV \% & 15.45 & 21.74 & & 33.62 & 20.1 & & 27.75 & \\
\hline & $\operatorname{LSD}(0.05)$ & 1503 & 1472 & & & 927 & & 913 & \\
\hline & Genotype (G) & & & & & & & * & \\
\hline & Environment (E) & & & & & & & $* *$ & \\
\hline & $G \times E$ & & & & & & & - & \\
\hline
\end{tabular}

The genotype S99 TLWQ-HG-AB had higher mean grain yield performance than the ideal genotype created by the GGE-biplot model. It is also closer to the performance line; hence it is consider more stable genotype (Fig. 1).

Based on regression analysis again the genotype S99 TLWQ-HG-AB produced the higher mean grain yield followed by S99 TLYQ-B and improved normal check across environments. It showed that these two QPM genotypes performed well in both rich and poor environments (Fig. 2). The regression coefficient (b) of S99 TLWQ-HG-AB and farmers' variety had greater than 1 (b $>1$ ) i. e. 1.24 and 1.26 respectively, these are above average stable genotype and specifically adapted to high yielding environments. S01 SIYQ and S99 TLYQ-B have regression coefficient (b) close to 1 . The genotype S99 TLYQ-B had higher mean grain yield over locations. It is well adapted to all environments and is an average stable genotype. S01 SIYQ had low mean grain yield, it has average stability and poorly adapted to all environments (Finley et al 1963) (Table 3).

Table 3. Mean grain yield and estimate of stability parameters in maize genotypes

\begin{tabular}{l|l|l|l|l}
\hline Genotypes & Mean & $\mathbf{b}$ & $\mathbf{R}^{2}$ & SE \\
\hline S99TLYQ-B & 3934 & 0.94 & 0.33 & 2023 \\
S99 TLWQ-HG-AB & $\mathbf{4 8 9 9}$ & $\mathbf{1 . 2 4}$ & $\mathbf{0 . 9 0}$ & $\mathbf{6 1 5}$ \\
S01 SIWQ-2 & 4300 & 0.68 & 0.95 & 312 \\
S01 SIWQ-3 & 4204 & 0.83 & 0.86 & 520 \\
S01 SIYQ & 3633 & 0.98 & 0.65 & 1088 \\
Imp. Chk. (Mana-3) & $\mathbf{4 4 3 6}$ & $\mathbf{0 . 9 3}$ & $\mathbf{0 . 5 9}$ & $\mathbf{1 1 7 9}$ \\
Farmers'Var.(L.Chk) & $\mathbf{3 1 9 1}$ & $\mathbf{1 . 2 6}$ & $\mathbf{0 . 8 5}$ & $\mathbf{8 1 7}$ \\
Grand Mean & $\mathbf{4 0 4 9}$ & & & \\
\hline
\end{tabular}


Exotic QPM genotypes tested under 4 hill environments of Nepal showed significant variation for grain yield, days to flowering, plant and ear height, husk cover tightness and plant aspect. QPM genotypes out yielded the improved normal checks and were also highly stable. Two QPM genotypes, S99 TLWQ-HG$\mathrm{AB}$ (white grain) and S99 TLYQ-B (yellow grain) were higher yielder than the improved normal check Manakamana-3. The first genotype performed very well across the hill environments and was liked by farmers. It should go to the farmers' field in the hills for general cultivation.

\section{Acknowledgement}

The authors are grateful to the Hill Maize Research Project (HMRP) for supporting this study. We would like to appreciate the support and guidance provided by Director of Crops and Horticulture, NARC, Mr. J. B. Chhetri, Mr. N. L. Dhakal, and Mr. R. P. Ghimire of NMRP Rampur for their involvement on the QPM experiments conduction and data recording. Finally, we would like to express our sincere thanks to all the station chiefs and technical staff for their field support.

\section{References}

BPSD, 2006-2007. Agri-Business Promotion and Statistics Division (ABPSD). Ministry of Agriculture and Cooperatives (MOAC), Singh Durbar, Kathmandu, Nepal.

Bressani, R., 1995. Quality protein maize In: Proceedings of the International Symposium on Quality Protein Maize (Eds Larkins, B. A. and Mertz, E.T.). EMBRAPA/ CNPMS, Sete Lagaos, Brazil. pp. 41-63.

Bressani, R. 1991. Protein quality of high lysine maize for humans. Cereal Foods World 36: 806- 811.

Finley, K.W. and G.N.Wilkinson.1963.The analysis of adaptations in plant breeding programme. Australian Journal of Agricultural Research.14: 742-754.
F.A.O., 1992. Maize in human nutrition. FAO, Rome.

Graham, G. G., R.P. Placko, and WC. Maclean, Journal of Nutrition. 1980, 110: 1070-1074.

Hugo, Cordova. 2000. Quality protein maize: Improved nutrition and livelihoods for the poor. Maize Research Highlights 1999-2000, CIMMYT. pp. 27 $-31$.

Kies, C., E.R. Williams and H.M. Fox. 1965. Determination of first-limiting nitrogenous factors in corn protein for nitrogen retention in human adults. Journal of Nutrition. 86; 350

Mertz, E.T., L.S. Bates, and O.E. Nelson. 1964. Mutant gene that changes protein composition and in increase lysine content of maize endosperm Science, 145; 279-280.

National Research Council.1988. Quality Protein Maize. National Academy Press, Washington DC.

Paes, M.C.D. and M.H. Bicudo. 199. Nutritional perspective of quality protein maize. In: proceedings of the International Symposium on Quality Protein Maize (Eds. Larkins, B.A. and Mertz, E.T.). EMBRAPA/CNPMS, Sete Lagaos, Brazil. pp. 65-78.

Upadhyay, S.R. et al. 2004. Germplasm Introduction, Evaluation and Utilization for Maize Improvement in Nepal. In: proceedings of the $24^{\text {th }}$ National Summer Crops Workshop on Maize Research and Production NARC, Khumaltar, Nepal. pp. 67-86.

Upadhyay S.R., D. Sharma, R.K. Mahato, K. Adhikari, T.R. Rijal, M.N. Paudel, R.B. Katuwal, B.B.Rokaya, T.B. Karki, K.H. Ghimire, B.N. Adhikari, B.P. Yadav, R. Yadav, L.N. Raya and J.B. Chhetri.2002. Introduction, Evaluation and Utilization of Exotic Maize Germplasm. Proceeding of the 23 $3^{\text {rd }}$ National Summer Crops Workshop on Maize Research and Production (July 2 - 4, 2002), NARC Khumaltar, Lalitpur, Nepal, pp. $37-76$.

Yan, W. and M.S. Kang. 2002. GGE Biplot Analysis: A Graphical Tool for Breeders, Geneticists and Agronomists. CRC Press, New York, USA. 